\title{
The Biology, Medical Significance and Control of Processionary Caterpillars
}

\author{
Dr N R H Burgess \\ PhD, FRES, MIBiol \\ Adviser in Entomology to the MOD \\ Mr K N Chetwyn \\ Scientific Officer, Entomology Unit
}

Royal Army Medical College

\begin{abstract}
Introduction
Processionary caterpillars, the larvae of a number of species of moth, are equipped with barbed poison hairs which may cause severe dermal irritation when they come into contact with human skin. These caterpillars are common in many parts of the world where Service personnel are stationed, and have caused particular problems in Cyprus, Hong Kong and parts of BAOR. This defensive mechanism and the processionary behaviour of the larva, is characteristic of the four species involved, Thaumatopoea pityocampa, $T$. wilkinsoni, $T$. processionea and $T$. pinivora.
\end{abstract}

\section{Distribution}

The geographical distribution of the moths covers continental Europe, southward to the Mediterranean and eastwards to Bulgaria and Greece. One species T. wilkinsoni is found in Cyprus (where it is a particular pest), parts of North Africa and the Middle East, including Israel.

\section{Description}

The adult moths of the genus Thaumatopoea have a wing span of about $25 \mathrm{~mm}$. The eyes are bare and ocelli are absent. The antennae of both sexes are combed as far as the tip. The proboscis projects backwards towards the thorax, which is thickset and covered in woolly hairs. The abdomen has a posterior bush, though in the male the hairs are of a stouter composition. Arising from the end of the abdomen is a single spur. $T$ pityocampa and $T$ wilkinsoni are closely related and of a similar appearance, the head possessing a chitinized cockscomb of four serrations (Fig. 1). The forewings are grey-white with darker transverse stripes and the hindwings are white. The ovum is $1-1.5 \mathrm{~mm}$ in diameter, white and spherical. The larva has a blue-black dorsal surface and whitish underside. The head is black, and the mirrors, areas of cuticle containing the poison hairs, are slightly raised. Abdominal segments are coloured yellow-brown and the long lateral hairs, are grey-

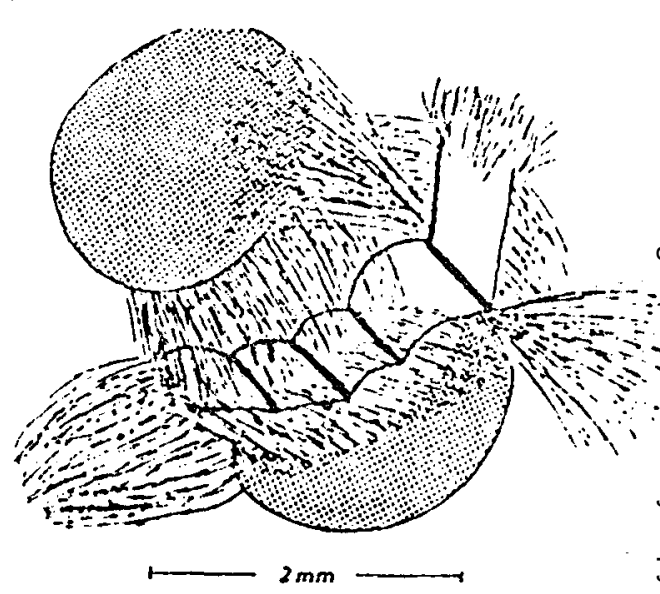

Fig. 1 Head of adult $T$. pityocampa showing chitifiea cockscomb of four serrations ${ }^{1}$.

white. The pupa is russet in colour and possess two hooks at the cremaster.

$T$ pityocampa, $T$ wilkinsoni and $T$ pinivora prefe to feed on trees of the genus Pinus with Cedrus sp局 as a second choice.

In comparison to $T$ pityocampa and $T$ wilkinson the adult of $T$ processionea has a flatter head and the serrated chitinized cockscomb is absent. The forewings are yellow-grey with the darker bars being indistinct or absent. Hindwings are grey-white $i \frac{7}{P}$ colour. The egg is white with flattened ends. The head of the larva is brown-black and the body blue grey with a yellow-grey underside. In general appea? ance the larva is not as hirsute as those of the other species. Members of this species are often found of oak trees.

\section{Life Cycle}

The adult moth emerges from the pupal case with the aid of the chitinized process on the head, the male emerging before the female. The preferregु 
flying period is two hours before and two hours after sunset and the distance travelled during this time may be in excess of $4 \mathrm{~km}$. During her first flight the female moth becomes sexually mature and starts to produce a sex attractant. Males attracted to the scent generally copulate with the female within one hour of their own emergence. Between thirty minutes and several hours after the copulation the female begins egg laying, moving in a spiral around a pine needle stem (Fig. 2). Each egg batch contains 7-300 eggs and ovi-position may take up to four hours.

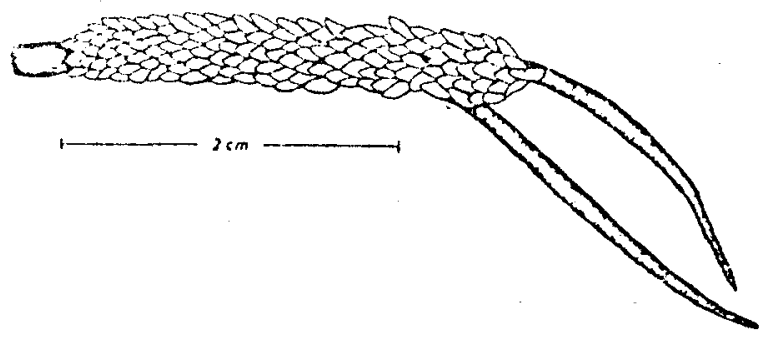

Fig. 2 Eggs, laid around a pine needle ${ }^{1}$.

First instar larvae emerge $30-45$ days after oviposition and spin a nest in the immediate vicinity of the egg cluster, within which they consume all available food. Larvae emerging later in the year, when temperatures are cooler, tend to construct their nests in parts of the tree which attract the most sunlight and therefore warmth. The insulating nature of the closely woven fibres can control the interior temperature of the nest to within $1.5^{\circ} \mathrm{C}$, and larvae have been reported to survive for ten hours at $10^{\circ} \mathrm{C}^{1}$.

It is prior to pupation that the presence of the 4th instar larvae is most apparent. Their migration procession in search of a suitable site for pupation brings them more into contact with people and animals. A procession first forms when larvae gather into a tight ball, which later flattens to a disc of larvae rotating around a single caterpillar. This central figure is often the leader of the procession when it becomes linear. Each larva in the procession maintains fore-and-aft contact with the others as they migrate to a suitable area in which to pupate. Pupation occurs in sunny situations in wooded areas, for example clearings and paths. The soil must be of a consistency which the larvae can penetrate, and the optimum soil temperature is $20-22^{\circ} \mathrm{C}$. Should the temperature drop sharply after the larvae have entered the soil, they may well re-emerge and, again in procession, move to a more suitable area, provided they have not yet begun to spin cocoons. The duration of the pupal stage is $4-5$ months in optimum conditions; this may be delayed by four months if the temperature above ground is unsuitable for larval viability. Temperatures in excess of $32^{\circ} \mathrm{C}$ are lethal to both eggs and larvae.

\section{Medical Significance}

The defensive mechanism by which the larvae of all stages may cause urtication consists of cuticular projections containing a poisonous fluid. The exact nature of the haemolytic poison is not known. These projections or spines are readily detachable and can easily penetrate tender skin, when the tip of the spine breaks off releasing the poison. The poison spines are situated on 'buttons' or 'mirrors' positioned laterally in pairs on each segment of the larva. Normally covered by folds of skin, the mirrors become exposed if the caterpillar is alarmed. Poison spines found on lepidopterous larvae are of two types, primitive and modified. Those found on the larvae of $T$ pityocampa are of the modified type (Fig. 3). Detached spines are sometimes present on pupal cases and newly emerged adults, where they may still cause dermal irritation to those who come into contact with them. Indeed in one case 600 out of 3000 Israeli soldiers encamped in a pine grove demonstrated urticaria and skin irritation although no living larvae were discovered in the area ${ }^{2}$.

The degree of injury depends on the species of caterpillar, the amount of poison injected and the
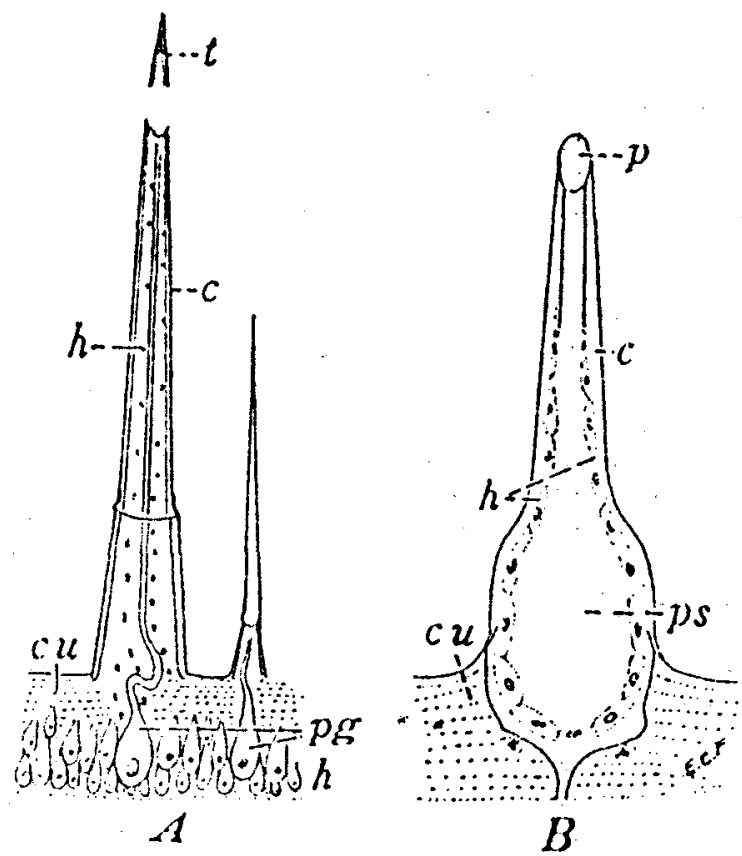

Fig. 3 Poisonous spines of lepidopterous larvae ${ }^{3}$. A primitive. B modified. 
sensitivity of the patient. Faust ${ }^{3}$ states at the time the poison is introduced "... there is a local burning, stinging sensation, the affected area becomes erythematous, then elevated and whitish, with a redder border extending radially as much as $2.5 \mathrm{~cm}$, and a peripheral reddish macular zone $2 \mathrm{~cm}$ beyond." Occasionally urticarral wheals may develop over the entire body, accompanied by systemic manifestations suggesting a neurotoxic syndrome. Further complications of poisoning in severe cases may cause muscle cramps, intense headaches, nervousness and tachycardia. Should the hairs come into contact with the conjunctiva, cornea or iris, local lesions may be produced with pseudotubercles around the hairs. Even superficial gangrene has been reported from the upper and lower eyelids, resulting in scarring, corneal ulceration and chronic conjunctivitis from a boy who came into contact with larvae of $T$. pinivora ${ }^{5}$.

The only satisfactory treatment appears to be the application of palliative lotions ${ }^{6}$. The use of tetracaine ointment is suggested, Benadryl, and occasionally codeine sulphate to relieve the pain. According to Wigglesworth ${ }^{7}$ the poison appears to liberate histamine in the tissues but not to produce it.

\section{Predators and Parasites}

The gregarious behaviour of the larva, involving the migratory habit and therefore a change of habitat, exposes it to a wide variety of predators and parasites. Several birds including the Great Tit (Parus major) appear to be unaffected by the poisonous hairs and may consume larvae in large quantities. Similarly predatory insects, for example the earwig Forficula auricularia, will consume the eggs. The largest group of parasitic insects which may seriously affect processionary caterpillars is the parasitic wasps (Order Hymenoptera). Ten or more species are involved, including Ooencyrtus pitocampae, Tetrastichus servadei, Trichogramma sp, $T$ evanescens, $T$ semblidis, Anastatus bifasciatus, Charitolophus sp, Meteorus versicolor, Coelichneumon rudis and Conomorium eremita.

Adult wasps lay eggs inside the caterpillar or in some cases the pupa. The eggs within the parasitized larva develop and emerge once the moth has pupated. In Cyprus where the larva of $T$ wilkinsoni is a common pest, $O$ pityocampae, $A$ bifasciatus and Conomorium eremita are reported as effective parasites $^{8}$. Other insects known to parasitize the larva of Thaumatopoea $s p$ belong to the Order Diptera and include Villa brunnea (Bombyliidae), Compsilura concinnata and Tricholyga segregata (Tachinidae). Georgiou $^{8}$ reports the two tachinids from Cyprus.

The larva is also known to be susceptible to at least two viruses Borrelinavirus pityocampae and
Smithiavirus pityocampae, isolates of which have been found in large numbers in the fat body an tracheal systems of dead larvae. The susceptibility of the larva and pupa to fungal disease is also roported $^{1}$, but it is difficult to quantify the degree क्ष pathogenicity. Fungi isolated include: Beuveria bassiana, Paecilomyces fumoso-roseus, $P$ farinost $\overline{\bar{s}}$. Cordyceps sp and Metarrhyzum anisopliae.

\section{Control}

Control measures used against processionary cate pillars may be physical, chemical or biological. ڤै

Physical control can only be used successfully against the larva while it is still in the nest. The nests, and the branches to which they are attached are carefully cut from the tree and burnt. Th method was used successfully in Spain in 1969-70 control processionary caterpillars infesting 52,00 hectares of land.

Chemical control is reported to be a long and expensive process involving the use of residual in secticides in infested areas. It is possible that perf tration of the nest by insecticides is poor and climatic factors, rainfall in particular, may lower the amount of available insecticide, thus reducing the efficiency of the control programme. Uitra-two valume (ULV) application and thermal fogging using non-residual insecticides have been used Cyprus against $T$ wilkinsoni but no figures are avito able to indicate the effectiveness of this methoob

Biological control involves the use of Baci thuringiensis, a selective insect pathogen. This metero was used successfully in France in 1958-9 with average mortality rate of $81 \%$ in treated areas, as opposed to $10 \%$ in untreated areas ${ }^{1}$.

In Italy $B$. thuringiensis was used against $T$. will $k^{\mathbb{Q}}$ insoni. The bacteria were formulated as a suspen $\overrightarrow{\overrightarrow{0}}$ sion of $30 \times 10^{6}$ spores/g. and applied at a rate o $6 \mathrm{~kg} / \mathrm{ha}$. by helicopter. The mortality rate varief between $62.5 \%$ and $99.8 \%$. Other countries whick have successfully used $B$ thuringiensis include BuF garia, Yugoslavia and Greece ${ }^{1}$.

\section{Discussion}

The urticarial lesions produced by some species of Thaumatopoea are sometimes sufficiently severe tô make this insect a serious nuisance.

Further observations into the biology of the insect may result in more efficient methods of controB Chemical control is undoubtedly the most economio and labour saving method used, but may also resul? in the destruction of the indigenous predators an parasites. The treatment of individuals affected b the poisonous hairs of processionary caterpillars, the biochemistry of the poison involved, and the way in which it affects tissues requires further investigation 


\section{REFERENCES}

1 Schwenke, W. Die Forstschadlinge. Europas. Paul Paray; Hamburg and Berlin: 1978.

2 Herms, W B. Medical Entomology, 6th ed. Macmillan; New York: 1969.

3 Faust, E C, Beaver, P C and Jung, R C. A nimal Agents and Vectors of Human Disease. 4th ed. Lea and Febiger; Philadelphia: 1975.

4 LuCAS, T A. Poisoning by Megalopyge opercularis. $J$ Am Med Assoc 1942; 119: 877-880.
5 Cheverton, $\mathbf{R}$ L. Irritation Caused by Contact with Processionary Caterpillars. Trans $R$ Soc Trop Med Hyg 1936; 29: 555-557.

6 Randel, H W. Caterpillar Urticaria in the Panama Zone: Report of Five Cases. In Buckley, E E and Porges, (eds). Venoms. Amer Assoc. Adv Sci Publ; 44: 1956.

7 WIGGLESWORTH, V B. The Life of Insects. Wiedenfeld \& Nicholson; London: 1956.

8 Georghiou, G P. The Insects and Mites of Cyprus. Kiphissia; Athens : 1977.

\section{BANKERS’ ORDER}

From (NAME AND RANK IN BLOCK LETTERS)

To the Manager

Please pay Messrs. Williams \& Glyn's Bank LtD., Lawrie House, Victoria Road, Farnborough GU14 7PA, for the credit of the funds of the Journal of the Royal Army Medical Corps, account number 14824634, the sum of

\section{${ }^{*} £ 10.00$ Journal and Magazine or \\ * $£ 8.00$ Journal only or \\ ${ }^{\star} £ 2.40$ Magazine only}

being my subscription for the year beginning 1st $19 \ldots . .$. and continue such payments yearly on the 1st till further notice.

Full Postal Address 